\title{
Contact Dilemma: The Malady of African Union Mission in Somalia (AMISOM) Troops
}

\author{
William Oluoch Ligawa', Odhiambo Elijah Onyango Standslause', \\ Mohamed Hussein Rahoy ${ }^{2}$ \\ ${ }^{1}$ Department of Peace and Conflict Studies, Masinde Muliro University of Science \& Technology, Gilgil, Kenya \\ ${ }^{2}$ Department of Peace and Conflict Studies, Kenyatta University, Gilgil, Kenya \\ Email: ligwawilson@gmail.com
}

Received 28 July 2016; accepted 16 August 2016; published 19 August 2016

Copyright (C) 2016 by authors and OALib.

This work is licensed under the Creative Commons Attribution International License (CC BY). http://creativecommons.org/licenses/by/4.0/

(c) (i) Open Access

\section{Abstract}

The collapse of Somali Government in the early 1990s left the state in the hands of predatory war lords who wrecked the country into havoc. The country has remained in a state of violent conflict for nearly over two decades. Intervention of United Nations Operations in Somalia failed to meet its objectives leaving the vulnerable population at the mercy of warlords when it finally withdrew its troops from the war torn nation. Despite the efforts of AMISOM troops to degrade the capability of Al Shabaab, little has been achieved. The militant group seems to be attacking the troops with vigour and renewed strength. With new barbaric counterinsurgency tactics, the terror group is regaining holds in the previously liberated regions. The soldiers tend to flee when they get engagements with Al Shabaab. They are unable to hold and suppress the firepower during contact. Consequently, the soldiers go into a flight mode turning their defensive position into a rout. This act is proving to be catastrophic to the mission since it occasions fatalities to the troops. Some who miss in action get lost into the hostile enemy territory. It is in this context that the study reports ways in which this malady can be curbed through the lens of contact dilemma.

\section{Keywords}

Militia, Contact Dilemma, Al Shabaab, Peace Support Operations, Intervention, Contact, Engagements

Subject Areas: Military Science

\section{Introduction}

Somalia has been embroiled in protracted conflict since ousting of the President Said Barre. To this end, there have been various peace support operations which have been mounted in Somalia. Despite these peace support 
operations, including the ongoing one by the AU Mission in Somalia (AMISOM), durable peace still remains elusive. AMISOM is supposed to neutralize Al Shabaab’s menace. Federal Government of Somalia (FGS) cannot operate in unstable environment. Al Shabaab is the military wing of the former Islamic Courts Union (ICU) which was crushed by the Ethiopian forces. This militant group has become too active thus launching its offensive actions against AMISOM troops. The Islamic group wants to take over the government from the FGS. One of the mandates of AMISOM is to subdue the armed groups creating conducive atmosphere for the Somali government to stabilize and pick up the normal functions of a state before AMISOM exits.

Institutional building of Somalia started early in 1991 with the intervention of UNOSOM I and II. The concerted efforts yielded little success. It sounds disturbingly familiar to observers of contemporary efforts to build Somali state institutions that many of the same dynamics at play in the 1980s persist today, bedeviling both Somalis and foreigners attempting to revive functional and accountable governmental institutions. The fact that these pathologies have now been a dominant part of the Somali political landscape for 35 years suggests that explanations cannot be reduced to relatively recent factors such as warlordism. The protracted nature of the crisis has also contributed to the rise of a political subculture among much of the country's small political elite that is soaked in impunity, corruption, and collusion, reducing national political life to the art of unapologetic embezzlement regardless of who is nominally in power. To the extent that this behavior has become the "new normal" in Somali politics, and deeply embedded in the shared norms of rival elites, it will be challenging to reverse. Many theories have been put forward to aid in understanding of the persistence of the Somalia conflict. It is in this context that the researchers have come up with contact dilemma to give a yard stick measure for the ongoing peace support operations in Somalia.

Attempt at first intervention by UN and international community proved disastrous; US lost her 18 soldiers in operation christened "Operation Serpent Gothic" and 23 Pakistani soldiers [1]. The operation was aimed at capturing the notorious warlord named Gen Aiid Farah. He was profiteering from the humanitarian aid thus perpetuating predatory violence. By 1995, the mission proved unattainable and the US soldiers had to vacate Mogadishu for Washington. Lessons were learnt but is seems AMISOM has not incorporated the lesson learnt in its current wake to pacify the Horn of Africa. When troops operate under chapter VII of the UN Charter, they use force. Military interventions involve the use of coercive force to subdue the armed groups in Somalia.

It is difficult to construct a scientific theory for the conduct of war. Attempts have failed and some people think it is impossible since it deals with issues that no permanent law can provide for [2]. One agrees that the whole range of propositions can be demonstrated without difficulty; defense is the stronger form of fighting with a negative purpose; attack is the weaker form of a positive purpose; that major success brings about minor ones; that a demonstration is a weaker use of force than a real attack; that a victory consists not only in the occupation of the battlefield but in the destruction of the enemy's physical and psychic forces; that success is always the greatest at the point where victory was gained; that a turning movement can only be justified by general superiority; that flank positions are governed by the same direction and that every attack loses impetus as it progresses.

Battlefield presents a lot of fog to the soldiers. The theatre is quite fluid and nothing remains predictable. Murkiness of war environment leaves soldiers with mortal fright. Peace support operations calls for troops from different countries with different national interests. These soldiers fight in foreign countries far away from their motherlands. With the rugged and difficult terrain, fighting in the African deserts, Savannah grassland and jungles becomes such a risky affair for any nation [3]. African conflicts are violent in nature. During UNOSOM operations, US lost 18 marines in one attack only whereas Pakistani lost 25 soldiers [4].

With conflicts still simmering in Somalia, it is unimaginable that peace support operations will diminish. The long-term effects these conflagrations will have on development on the African continent are multi-fold. The missions will inevitably have manifest or positive, intended, as well as latent or negative, unintended consequences for the host populations of the different conflict-ridden countries involved. Yet, the soldiers are supposed to protect the civilians. The Somalis have suffered atrocities meted on them by the warlords and the militant groups [5]. Rapacious violence has occasioned many deaths thus calling for robust operations. With the end of the cold war, the room for robust action increased. In 2000, the UN Secretary-General presented the Brahimi Report on the future of peacekeeping, suggesting more vigorous action. Following this report, soldiers have been given explicit authority to use force to protect civilians in peace support operations in Africa. The provisional guidelines with respect to rules of engagement in operations likewise demonstrate a quest for more forceful action to protect local civilians if the need arises [6]. Blocq notes that in peace support operation is laudatory, 
but the question may be raised whether the regulation can and will be executed. Can individual soldiers take up the Responsibility to Protect? Are they morally and psychologically prepared to kill and risk their lives in peacekeeping operations, for people they do not know, in places that they may never have heard of before? [7].

\section{Contact Dilemma}

Soldiers have been accused of failing to perform their duties. Instead, when they come under the enemy fire they tend to run away. They do not want to brave the enemy fire. This has occasioned "contact dilemma" Scholars have not done any empirical research to give a theoretical analysis to the phenomenon. One respondent noticed that during the occasions when troops established contact with the militant groups, the troops were not courageous enough. Some of them had to run away. And in some defended localities when the bases were attacked, the soldiers opted to running away rather than fighting back. Failure to hold ground firm and battling Al Shabaab resulted into unnecessary casualties. Even the developed nations find it hard sending their soldiers into these war-torn regions as seen in Somalia and Rwanda during 1994 Genocide [8]. It is in this regard that the study developed a theoretical tool (contact dilemma) to facilitate practical analysis of the phenomenon. In the UN operations in Rwanda and Bosnia, some skeptics, implicitly and explicitly, claimed that cowardice and unassertiveness of Belgian and Dutch peacekeepers, respectively, were crucial factors in the ultimate dramas. Although the debacles in Rwanda and Bosnia were by no means a good yardstick for drawing conclusions about the moral and psychological preparedness of soldiers to fight in peace support operations-the mandates in Rwanda and Bosnia were different from the robust contemporary mandates for peacekeeping, weapons and numbers of troops in Rwanda and Bosnia were inadequate to provide the protection that was needed [9]. Preparedness to fight remains a complex phenomenon. During combat, soldiers get killed and other get maimed permanently. In the third world countries, compensation takes too long or they do not even get paid at all. When US lost 18 soldiers in the marine raid in Mogadishu, they withdrew their soldiers from Somalia in 1995.

Grossman submits that civil society sometimes assumes that soldiers are prepared to fight in any military operation. Both readiness to kill and preparedness to die are taken as fact [10]. However, reality demonstrates that military personnel need to actually conquer their aversion of killing and constantly suppress their fear of dying [11]. Killing is commonly perceived as a moral wrong. Frequently, killing involves pain for the dying human being. It causes grief among family and friends, and it violates ethical principles such as "respect for autonomy" and "sanctity of life" [12]. According to Marshall the aforementioned moral considerations are so deeply ingrained in the soldier that they become an emotional obstacle for him or her in war-type situations [13]. Not only aversion toward killing but also fear of dying influence the behavior of soldiers. Human beings are generally not inclined to risk their lives. Like animals, human beings have a natural desire for self-preservation. This desire is boosted by an increasing awareness of the value of life. Not having to worry about some basic means such as food, shelter, and security strengthens the appreciation for life. Many people in Western states have more time to reflect on life, and even though there is a tendency to get trapped in material desires, when death becomes involved everything seems to fade. As a result, soldiers from developed countries appear to be becoming more cautious in war-type situations. Career-conscious commanding officers heighten that cautiousness further. Casualties among their personnel diminish their chance of promotion, driving them to more risk-aversive behavior.

Fear of dying and aversion toward killing are natural reactions to the situation on the battlefield. They will always be present, and no attempt should be made to fully eliminate them in combat. Such elimination would require dehumanization of the enemy and possibly of local civilians. Also, it could result in irresponsible and careless action on behalf of the fearless soldier, jeopardizing his or her entire environment. Thus, fear of dying and aversion toward killing should be cherished; it is uncontrolled fear and unlimited aversion toward killing that need to be addressed [14]. Studies in combat motivation dealing with the question of why soldiers fight, demonstrate to an important extent how soldiers cope with and control both their aversion of killing and their fear of dying. Reasons to fight range from grand ideological objectives, which chiefly play out on the ontological level, to basic stimuli such as self-preservation, which manifest themselves on a concrete psychological level. Fernando argues that distinctions have been made among motivation, impulses, motives, and morale, but a clear categorization of reasons to fight is challenging, to say the least [15]. In this article, reasons to fight are understood as all elements in the social and moral psychological process that precede, lead to, and trigger action. Examples include love of glory, self-preservation, unit cohesion and comradeship, discipline, money, fear of social 
and physical retribution, hatred of the enemy, and belief in the ideological, strategic, and tactical goals of operations. With the plethora of reasons to fight, it is hard to measure the location of particular elements within the general moral and psychological preparedness of individual soldiers. That role is dependent on personal, temporal, and operational circumstances. Most likely, individual soldiers will not even know themselves exactly why they fight. Nonetheless, across time, certain patterns have been identified.

Between the fifteenth century and the late eighteenth century, European armies-which certainly had not the degree of organization and professionalism that we see today—-were made up of a variety of soldiers, including volunteers, foreigners, and sometimes even conscripts. The volunteers were the largest in number, joining for money, adventure, religious convictions, or family traditions. Most of the foreign soldiers were mercenaries. Mjoset and Holde conceded that they were outcasts within their respective societies and would align with various units for the sake of money and escaping some unpleasant fate or future. Conscription was a rather unusual phenomenon. Conscripts were typically criminals, appointed by local magistrates for army service. The Nordic states of Europe-Sweden, Denmark, and Norway - were the only ones with a system of compulsory military service. While the system produced a relatively sizeable force, the conscripts were not greatly motivated to fight. In fact, many young men from the Nordic states fled the country or inflicted injuries on themselves to escape military service.

A decisive change in the makeup of armies materialized when the French introduced the citizen-soldier [16]. Posen explained that, in the competitive system of international politics that reigned in Europe in the late eighteenth and early nineteenth century, Napoleon struggled with the question about producing and retaining a sizeable and combat effective army. The French ruler realized that willingness to sign up and fight and a commitment to the outcome were crucial factors in achieving his objective. Thus, a campaign was launched to promote a national identity, loyalty to the French nation, and a feeling of belonging, which would serve the military objectives According to Posen Napoleon actively promoted nationalism to produce the conditions for a mass army.

The humiliating defeat of the Prussians in 1806 created awareness with the Prussians that the French mass army could be resisted only by a similar mass army. Recruitment of foreigners was eliminated and compulsory service was introduced. As a result, the size of the Prussian armed forces expanded substantially-from 60,000 to 270,000 within a year - and the connection between the army and the people intensified. Nevertheless, the national identity that was created by the French was different from the identity of the Prussians because, among others, the Prussian monarchs feared that the type of nationalism that was governing France, which was based on ideas of egalitarianism and grounded in the French Revolution, would crumble away the royal power. Therefore, the Prussian rulers emphasized loyalty to the monarchy. Nationalism in the Prussian army was, to an important extent, founded on a "passionate but diffuse bitterness and hatred of the world" after the defeat by France.

While all European countries, as well as the United States, at one point or another introduced a national army and some form of conscription, the roles and forms of nationalism were different in each case. Sometimes conscription and nationalism were used for the socialization of the country, such as in Austria, where the elite tried to "displace social unrest" outward by turning the loyalties of young men to their villages into loyalties to their nation. In other cases, such as in the United States, nationalism basically came from below and was more a matter of citizen service process that ran, in part, analogous to the formation of national armies was the rise of military professionalism in Western society. That professionalism transpired in the form of an officer corps that was, and still is, guided by expertise—officers with specialized skills and knowledge—by responsibility and submission toward society and by corporateness - a sense of organic unity. Huntington explained how military professionalism came about: "The growth of population in the eighteenth and nineteenth centuries, the development of technology, the beginning of industrialism, and the rise of urbanism—all contributed to increased functional specialization and division of labor.

The parallels between Huntington's explanation for military professionalism on one hand, and explication regarding the advance of nationalism—resulting from the need for a division of labor in industrial society — on the other hand, are striking. Not surprisingly, Huntinton argued, "A professional soldier is imbued with the ideal of service to the nation. In practice, he must be loyal to some single institution generally accepted as embodying the authority of the nation. Professionalism and nationalism are necessarily connected. But while this bond between the professional soldier and the nation is manifest and real, it should not obscure the distance that professionalism also creates. Professionalism implies a certain detachment from political affairs. Politics forms the realm of other experts and should therefore not be invaded by the military. This situation sometimes creates ten- 
sion. On one hand, the professional soldier is expected to be devoted to society and care about it, but on the other hand, or just because of that, it must stay aloof. In present-day politics and civil-military relations, this tension sometimes plays out in the phenomenon of "shirking” by the military.

\subsection{The Persistent Characteristics of Contact-Dilemma}

Battlefield is marked by fog. Troops are deployed on ground and aligned for combat. Success is realized from aggressive, calculated and decisive use of combat power. Soldiers must be ready for combat and respond appropriately to the enemy fire. If soldiers cannot withstand the enemy's fire and opt to run away, this act of cowardice jeopardizes the AMISOM's operations. There are persistent characteristics of contact dilemma; friction; uncertainty and chaos; violence and danger; and Human stress.

\subsubsection{Hostility}

When troop establishes contact with the armed groups, soldiers tend to lose initiative. The act of hostility and friction in the theatre of war causes confusion. This is the force that makes the simple task look difficult and the difficult ones seemingly impossible. Friction could be mental or physical. An informant elucidated that during contact with the armed groups, all over sudden everything seem to freeze in time. The smell of gun powder, gun shots and bomb explosions can make one run away if one has not been well trained or one lacks equipment. The effects of friction can be overcome by determination, high morale, a sound organization that is understood by all men and effective system.

\subsubsection{Uncertainty and Disorder}

Combat is uncertain and chaotic. No plan survives contact. When Al Shabaab attacks, they leave a tail of destruction. The battle is quite bloody owing to their barbaric tactics. Improvised explosive devices (IED) explode killing dozens of soldiers before reinforcing it with a barrage of small fire arms and rocket propelled grenades. It is therefore conducted against a background of possibilities arrived at by balancing of risks. However, risk is reduced at by the availability of intelligence on the enemy. With lack of information about activities of Al Shabaab, the operations are thus conducted blindly. Another informant expressed that most of the operations are not intelligence driven. The contingents do not share information amongst themselves. AMISOM is yet to develop a synchronized information collection and gathering mechanisms. Lack of prior information predisposes soldiers to contact-dilemma. Prior information prepares the troops physically and psychologically. Readying of troops start by rehearsing drills, and conducting anti-ambush drills. Seizure of initiatives is key to exploiting chaos and uncertainty at the theatre.

\subsubsection{Violence and Danger}

The enduring mortal fright in the battlefield is real. Overwhelming violence can be applied or threatened to be used by application of combat power. At tactical level, troops must apply lethal force to defeat the enemy. Weapons embedded within the fighting units should be able to deliver the required fire power. One respondent narrated that one cannot fight an enemy who is more equipped than you are; one is bound to be overwhelmed by that firepower thus turning the base into a rout. Violence brings fear and danger and all men fear. Leaders have to train their soldiers to master the use of weapons and equipment. It harnesses courage from within the soldiers necessitating success.

\subsubsection{Human Stress}

The will of the individual soldier to stand and fight, triangulated across their fighting unit determines the success of mission at hand. The resolve to fight has to be manifested within the soldiers and commanders. Competent leadership and efficient drills are vital in the face of danger. Combat motivation should be expressed in the soldiers' wake to accomplish any given task. AMISOM should provide specialists to help soldiers in managing combat stress and their psychological conditions to be ascertained.

\subsection{Implications of Contact-Dilemma}

Contact dilemma becomes a defining moment for the PSOs. Al Shabaab wants to maximize on the battle field confusions to their advantage. They launch lightening attacks on the AMISOM bases with overwhelming lethal- 
ity. The barbaric modes of offensive are quite intimidating and deathly to the troops. Al Shabaab's commanders exploits that to their success. They also consolidate their firepower and deliver it at decisive points. With powerful machine guns, 47AKs of the troops are a no match.

Troops can only overcome this situation with proper training and equipment. One cannot fight a superior enemy with inferior weapons. The researcher observed that Al Shabaab has superior weaponry. This complicates the battle equation. Professionalism of soldiers should be complemented by appropriate equipment. One informant admitted that the war against Al Shabaab needs sound tactical movements coupled with the necessary weapons. So long as these militants own such powerful machine guns, degrading their capability is far from reality not unless the troops get modern equipment which can be used to counter their offensives.

\section{Conclusion}

Peace support operations offer the best platform for stabilization Somalia. Troops are required to fulfill their duties. War is violent in nature. It occasions death, injuries which could lead to permanent disabilities, and physical and emotional sufferings. Soldiers are trained to conduct risky operations. Such missions could be dangerous because the militant has become more aggressive in terms of their operations. They have increased their operational momentum thus attacks on AMISOM bases have increased significantly. Contact dilemma is therefore a challenge that AMISOM will have to contend with. Soldiers have to be prepared and trained both physically and psychologically to undertake intervention missions. The troops need to be equipped with the necessary weaponry so that they are able to degrade the armed group's fighting capability. In the fight against contemporary insurgency, soldiers have to be adequately resourced.

\section{Recommendations}

Initial estimations deal with preparedness for the tasks at hand. Military campaign requires detailed planning before they are launched. Planning espouses the exit strategy so that when required threshold is achieved the troops can pull out. This exercise is usually laborious because peace support operation is bound to fail or succeed from the planning. At the inception if planners get it all wrong then chances are, the mission could end up being aborted halfway. With the cut of the budget by major donors, most of the operations are likely to be crippled. Protraction of the operation should have been foresighted for contingency measures.

Necessary equipment should be availed at the theatre. Today's insurgency is complicated. It is fought out by well trained and armed gangs. Attack helicopters and armed drones dominate the modern battle space. Poorly armed troops cannot battle armed militants. Boko haram (the Islamic militant group occupying Northeastern parts of Nigeria, Chad, Niger and Cameroon forest) abducted 276 girls from a school in Nigeria and the government forces have been unable to rescue them. One of the battalions was court martialed and charged with mutiny. The soldiers downed their guns citing lack of weaponry. Al Shabaab has affiliations to Boko haram and soon if the loopholes are not tightened they are likely to go the Boko haram style. AMISOM should equip her troops. Morale boosting is part of planning. Soldiers should be motivated to fight and that comes with relatively good emoluments.

Lying plans and calculations calls for training of the personnel involved. Predeployment training should be effective. This prepares troops of what they are likely to meet in the arena. Acclimatization is necessary considering the unfriendly climate of HoA. The climate is hostile and without proper training, soldiers would have to endure sobering realities of the Somalia climate. Training has to be objective and realistic. For the AMISOM troops fighting of irregular warfare is supposed to dominate their training calendar. Guerilla warfare tactics are crucial. Fighting asymmetrical warfare with fast changing tactics, require appropriate trainings. Their model of fighting seems to be changing fast and thus catching soldiers off guard. The use of VBIED has not been seen in the past by the contemporary military observers. When the blast goes off, it is intimately supported by suicide bombers who dive into the trenches. The enemy action smoked soldiers out of their poorly built trenches, rendering the outpost unattainable. Breaching the gaps within the defence and exploding it, leaves soldiers too vulnerable for enemy fire.

Contingent commanders conduct reconnaissance on the ground or sector he is likely to deploy. Adequate preparations are made and drawn out of that. Carrying out even map reconnaissance is vital. Military engagements need appropriate leadership and management. The commanders up to the lowest cadre should have relevant training. Success of peace support operations at contact level lies with commander or the team leader on the 
ground. Effective, sound and timely decision making are crucial for operations in such a hostile environment.

All of war is about will. Those who wage war must impose our will on the enemy is [war's] object. To secure that object, we must render the enemy powerless. Down through history, rendering the enemy powerless most often meant denying him the means to resist by defeating his fielded military forces. There are, however, other ways of rendering an enemy powerless or otherwise convincing him to accede to one's will. Collectively called strategic attack (SA), they have a historical pedigree that long predates the name. Victory normally requires offensive action; thus, SA is the proactive and aggressive portion of strategic operations, which also include strategic defense and other strategic operations all of which should directly achieve AMISOM's strategic objectives. Chocking their source of income inhibits their ability to operate. AMISOM with the help of FGS should deny the armed militant group the revenue they are earning from charcoal business.

Defeating or coercing adversaries requires effects-based SA. That is, one must design actions against adversary systems to create specific desired effects that contribute directly to achieving military and political objectives, attainment of which delivers a set of end-state conditions that confers continuing advantage. Furthermore, one must do so while avoiding specific undesired effects that will hamper the creation of such conditions. The conduct of SA encourages taking an effects-based approach to military operations. The phrase most directly is the key to understanding this aspect of SA. Oftentimes, the accumulation of tactical actions against the Al Shabaab also offers an effective way of achieving national security objectives; however, it frequently does not represent the most direct means in terms of level of effort or of targets selected. Such tactical victory against fielded forces often comes at a higher cost with regard to lives, treasure, time, and opportunities. So SA may prove more efficient as well as more direct.

Every system has some sort of directing function; every human system has a leader or leaders. In many cases, attacks that neutralize these leaders can eliminate enemy resistance, rendering the enemy powerless. Historically, this has most often entailed directly attacking strategic leaders; moreover, AMISOM has the ability to attack the infrastructure that supports and connects that leadership function to the rest of the system. Of course, in today's context, one must conduct attacks on leadership in accordance with the law of armed conflict, which maintains that leaders must be legitimate military targets. It is often possible to target an adversary's means of conducting or continuing a conflict. The support necessary to sustain resource-intensive modern warfare (even primitive war relies on resources of some sort) provides many lucrative targets, speeds the enemy's collapse, and removes options from enemy commanders. Securing various seaports have helped in denying Al Shabaab source of funding.

Many considerations distinguish the conduct of SA from that of more traditional counterforce warfare. The selection of targets differs, of course, as may the means of attacking them. The sophistication required to conduct SA successfully against modern systems entails a much greater intelligence-analysis cost than do operations that simply attrite enemy fielded forces. This necessitates the development of intelligence-federation partnerships with national-level agencies and sometimes even with intelligence services of foreign governments in order to analyze systems adequately. Commanders must ensure that such preparation work happens before crises develop and conflict ensues. Further, in counterforce operations it may be possible to gauge progress simply by counting numbers of enemy troops killed or pieces of equipment destroyed, but assessing the effects of SA demands much greater sophistication in choosing measures and indicators. It also calls for more patience from commanders and national leaders since progress toward the achievement of objectives may show few outward signs until one fulfills the objectives themselves.

Building of force is fundamental for the success of the operations. The strategic military power should be used to exploit vulnerabilities of the enemy. Commander should manoeuvre his forces to exploit enemy's weakness. Soldiers are configured and designed to fight. Failure to this engenders defeat in any battle space. Configuration draws in the perspective of fire power. Even the smallest fighting unit should be designed to fight. Support fire weapons are embedded in that unit. AMISOM should configure her outposts to carry out decisive operations on these militant groups.

Assessment of what makes Al Shabaab stick seems not to have been carried out. Centre of gravity (CoG), critical capabilities, critical requirements and critical vulnerabilities should have been discerned. These are perquisites to successful shaping operations. In threat integration, commander should endeavor to exploit the enemy's weaknesses. Enemy strengths are to be avoided. Anticipate that your opponent will attack your weakest point and prepare for that eventuality, while marshaling your forces to attack the enemy's weak point. Critical capabilities could be: secure bases for training, logistics, command, charismatic leadership, financial and, or technical know-how. AMISOM leadership should strive to identify these factors and counter them.

In the past, these critical vulnerabilities have been exploited by forces in offensive operations to create victo- 
ries. In every war, campaign, and battle in history one can normally (with the benefit of hindsight) identify a point where one side irrevocably started to win, and the other side to lose. In the 1940 battle for France it was the failure of French counterattacks against Guderian's bridgeheads on the Meuse that was the decisive act, making defeat of the Allied armies in Belgium inevitable. In the Yom Kippur War of 1973 it was Sharon's successful counterattack and crossing of the Suez Canal at Chinese Farm that doomed the Egyptian offensive. In the Battle of the Atlantic it was the closure of the mid-Atlantic "air gap" by long range Liberators in mid-1943 that proved decisive, finally ending. German U-boat surface operations and swinging the operational advantage to the Allies. The Russian counteroffensive at Stalingrad is a commonly cited turning point on the Eastern Front in World War II (although some historians argue that Hitler's war in Russia was not irretrievably lost until Kursk in 1943).

In each of these examples we can identify what Clausewitz described as a decisive act, which effectively caused the culmination of the opponent. Put another way they cause a favorable change in the situation or cause the threat to change or to cease planned and current activities. Decisive actions create an environment in which the enemy has either lost the physical capability or the will to resist. Once culmination point has been reached, victory becomes impossible unless the enemy unaccountably lets his opponent off the hook. Decisive acts are rarely "silver bullets" - single actions that alone cause the culmination and defeat of an enemy. Usually they will be the result of a number of major operations that allow one side to force the culmination of the other. French defeat at Sedan in 1940 followed German operational deception in Belgium and the Netherlands. The closure of the mid-Atlantic air gap in 1943 was just one of a long series of tactical, intelligence, and technical developments in the war of attrition between U-boat and merchantmen. The successful Soviet encirclement at Stalingrad depended on months of urban fighting to draw German reserves into the city. In our doctrine we describe these actions that support the decisive action as shaping operations. Shaping actions set conditions for decisive actions. Shaping makes the enemy vulnerable to attack and dictates the time and place for decisive actions.

Centers of gravity can exist at all levels of war-tactical, operational, strategic. But it is misleading to think of a single center of gravity existing at a particular level of war, as if each level is a discrete component rather than a continuum from small unit actions up to grand strategy. Indeed a center of gravity—both friendly and enemywill exist for every level of command that's got a combat mission, regardless of whereabouts within the levels of warfare that unit and mission sit.

AMISOM should thus maximize on air superiority. Al Shabaab should not be given freedom of action anymore. Until the recent airstrikes by the US drones which killed more than 150 recruits at a training camp in Raso; Northeast of Mogadishu, they have been doing their day patrols without any fear of air or ground attack from the AMISOM troops. Their source of sustenance should be choked so that they do not get the basic logistics support.

Blind operations can be dangerous for troops. Effective information gathering system should be developed. Information analysis should be contained in the Intelligence cells. Sufficient resources should be set aside for information gathering. Agencies and sources have to be maintained. One respondent noted that AMISOM lacks efficient information collection plan. The intelligence is also not shared amongst the contingents. Ramifications have been seen of the successful attacks by the armed groups on the AMISOM bases. Military operations are supposed to be intelligence driven and the failure to this can lead to fatal tactical blunders.

\section{References}

[1] Stupart, J. (2011) Jus Ad Bellum and Intervention in Somalia: Why a Military Response Can Still Work. Scientia Militaria: South African Journal of Military Studies, 39, 76-98. http://dx.doi.org/10.5787/39-2-112

[2] Clausewitz, C.V. (1940) On War. E.P. Dutton and Co., LTD, New York.

[3] Woever, O. (1998) Security, Insecurity and Asecurity in the West-European Non-War Community. In: Adler, E. and Barnett, M., Eds., Security Communities, 69-118. http://dx.doi.org/10.1017/CBO9780511598661.003

[4] Bachman, O. (2012) The African Standby Force: An Element of Prospective Multilevel Security Governance. IDS Bulletin, 43, 14-19. http://dx.doi.org/10.1111/j.1759-5436.2012.00331.x

[5] Nyambura, C.W. (2011) The Multifarious Interlinked Causes of Conflict in Somalia and the Way Forward. Journal of Language, Technology and Entrepreneurship in Africa, 3, 181-198. http://dx.doi.org/10.4314/jolte.v3i1.66718

[6] Blocq, D. (2010) Western Soldiers and the Protection of Local Civilians in UN Peacekeeping Operations: Is a Nationalist Orientation in the Armed Forces Hindering Our Preparedness to Fight? Armed Forces \& Society, 36, 290-309. 
http://dx.doi.org/10.1177/0095327X08330816

[7] Williams, P.D. (2012) The Peace and Security Council of the African Union: Evaluating an Embryonic International Institution. Journal of Modern African Studies, 47, 603-620. http://dx.doi.org/10.1017/S0022278X09990048

[8] Hesse, B. (2014) Two Generations, Two Interventions in One of the World's Most-Failed States: The United States, Kenya and Ethiopia in Somalia. Journal of Asian and African Studies, 1, 1-28. http://dx.doi.org/10.1177/0021909614552919

[9] Grossman, D. (1995) On Killing. Little, Brown Press, New York.

[10] Norman, R. (1995) Ethics, Killing and War. Cambridge University Press, Cambridge. http://dx.doi.org/10.1017/CBO9780511554568

[11] Marshall, L. (1947) Men against Fire: The Problem of Battle Command. University of Oklahoma Press, Norman.

[12] Born, R., Moelker, H. and Soeters, T. (1999) Krijgsmacht en Samenleving. Tilburg University Press, Tilburg.

[13] Ferdinand, R. (2000) Indigenous Mercenaries in the Service of European Imperialists: The Case of the Sepoys in the Early British-Indian Army: 1850-1900. Armed Forces \& Society, 7, 2-28.

[14] Mjoset, L. and Holde, S. (2002) Killing for the State, Dying for the Nation in The Comparative Study of Conscription in the Armed Forces. Elsevier, Oxford.

[15] Posen, B. (1993) Nationalism, the Mass Army, and Military Power. International Security, 18, 82-83. http://dx.doi.org/10.2307/2539098

[16] Huntington, S. (1967) The Soldier and the State. Harvard University Press, Cambridge.

\section{Submit or recommend next manuscript to OALib Journal and we will provide best service for you:}

- Publication frequency: Monthly

- 9 subject areas of science, technology and medicine

- Fair and rigorous peer-review system

- Fast publication process

- Article promotion in various social networking sites (LinkedIn, Facebook, Twitter, etc.)

- Maximum dissemination of your research work

Submit Your Paper Online: Click Here to Submit

Contact Us: service@oalib.com 